\title{
FILM DOKUMENTER SEBAGAI MEDIA INFORMASI KOMPETENSI KEAHLIAN SMK NEGERI 11 SEMARANG
}

\author{
Arie Atwa Magriyanti ${ }^{1}$, Hendri Rasminto ${ }^{2}$ \\ ${ }^{1}$ Progdi Desain Grafis Universitas Sains dan Teknologi Komputer Semarang, arie.atwa@stekom.ac.id \\ ${ }^{2}$ Progdi Manajemen Informatika Universitas Sains dan Teknologi Komputer Semarang, \\ hendri@ stekom.ac.id \\ Jl. Majapahit 605, Semarang, telp/fax : 024-6717201-02
}

\begin{tabular}{|c|c|}
\hline ARTICLE INFO & ABSTRACT \\
\hline $\begin{array}{l}\text { Article history: } \\
\text { Received } 30 \text { October } 2020 \\
\text { Received in revised form } 02 \text { November } 2020 \\
\text { Accepted } 10 \text { November } 2020 \\
\text { Available online } 12 \text { December } 2020\end{array}$ & $\begin{array}{l}\text { SMK Negeri } 11 \text { Semarang is a school that has four } \\
\text { competency skills, namely Graphic Preparation, } \\
\text { Graphic Production, Multimedia, and Animation. } \\
\text { Every time they enter the beginning of the school } \\
\text { year, school socialization and skills competencies } \\
\text { are carried out to new students through the Student } \\
\text { Orientation Period, using the lecture method from } \\
\text { each of the Head of Skills Competencies. } \\
\text { Researchers have created an attractive and } \\
\text { informative audio-visual presentation media, packed } \\
\text { with docudrama stories, namely documentary films. } \\
\text { The results of validation tests conducted by expert } \\
\text { experts and users show that the documentary films } \\
\text { that have been developed by researchers fall into the } \\
\text { very good criteria with a percentage of } 93.75 \% \text {. In } \\
\text { addition, through the use of the } 228 \text { new students as } \\
\text { respondents, it can be concluded that the } \\
\text { documentary film developed by the author falls into } \\
\text { the good criteria with a percentage of } 61 \% \text {. }\end{array}$ \\
\hline & Keywords: Film; Dokumenter; Informasi; Sosialisasi \\
\hline
\end{tabular}

\section{PENDAHULUAN}

Perkembangan ilmu pengetahuan dan teknologi, mempengaruhi pula perkembangan media komunikasi. Komunikasi adalah proses penyampaian pesan atau berbagai informasi kepada orang lain. Informasi yang terdapat pada sumber-sumber informasi terekam bermacam-macam bentuk, salah satunya adalah film dokumenter.

Film dokumenter merupakan film yang menceritakan sebuah kejadian nyata dengan kekuatan ide kreatornya dalam merangkai gambar-gambar menarik menjadi istimewa secara keseluruhan (Andi Fachruddin:2012). Bill Nichols (2001) juga menyebutkan bahwa film dokumenter adalah upaya menceritakan kembali sebuah kejadian atau realitas menggunakan fakta dan data. Adapun Misbach Yusa Biran mengatakan bahwa dokumenter adalah suatu dokumentasi yang diolah secara kreatif dan bertujuan untuk mempengaruhi (mempersuasi) penontonnya. Film dokumenter masih jarang dinikmati oleh seluruh masyarakat, namun jika dikemas dengan baik 
dan informatif, maka dapat menjadi tontonan yang menarik dan mengerti dengan apa yang diinformasikan.

SMK Negeri 11 Semarang adalah sekolah yang memiliki empat kompetensi keahlian (jurusan), yaitu Persiapan Grafika, Produksi Grafika, Multimedia, dan Animasi. Setiap memasuki awal tahun pelajaran, SMKN 11 Semarang melaksanakan Penerimaan Peserta Didik Baru (PPDB) dengan target siswa yang diterima sejumlah kurang lebih 540 siswa (15 kelas), yang terbagi menjadi 5 kelas Persiapan Grafika, 5 kelas Produksi Grafika, 3 kelas Multimedia, dan 2 kelas Animasi. Setelah berakhirnya proses PPDB, agenda sekolah selanjutnya adalah pelaksanaan Masa Orientasi Siswa (MOS). Untuk mempersiapkan siswa baru mampu mengikuti pembelajaran pada masing-masing kompetensi keahlian khususnya pelajaran produktif (kejuruan), maka saat pelaksaan MOS itulah diberikan informasi/sosialisasi profil masing-masing kompetensi keahlian.

Cara yang selama ini dilakukan SMKN 11 Semarang untuk mensosialisasikan pembelajaran masing-masing kompetensi keahlian saat MOS yaitu dengan metode ceramah dari masing-masing KKK (Ketua Kompetensi Keahlian) dan dengan perkenalan/ kunjungan masing-masing bengkel (tempat praktik). Menurut pengamatan penulis, karena pelaksanaan sosialisasi tersebut dilakukan secara bersamaan di satu ruang dengan jumlah peserta MOS yang banyak, saat KKK menjelaskan ada beberapa siswa yang tidak memperhatikan, terkadang ada yang berbicara sendiri, dan ada pula yang mengantuk. Selain itu, waktu yang diberikan kepada KKK hanya kurang lebih 30 menit, sehingga materi yang disampaikan terbatas. Sementara, pada saat peserta MOS mengunjungi bengkel praktik, dengan kapasitas ruang bengkel yang terbatas, tidak semua peserta MOS memperhatikan penjelasan tentang bagaimana praktik di setiap bengkel. Menurut penulis, dengan segala keterbatasan tersebut, pelaksanaan sosialisasi kompetensi keahlian yang selama ini dilakukan kurang maksimal.

Berdasarkan pemaparan di atas, maka film dokumenter bisa dijadikan sebagai media informasi kompetensi keahlian SMKN 11 Semarang dengan alasan: (1) Peserta MOS adalah siswa baru dari lulusan SMP atau sederajat, maka cocok jika diberikan tayangan yang mudah dipahami, berisi tentang ilmu pengetahuan dan dikemas dalam suatu alur cerita yang menarik; (2) Memberikan informasi yang dapat membantu pemahaman siswa baru tentang kompetensi keahlian, karena cerita dalam film dokumenter tersebut menceritakan tentang profil masingmasing kompetensi keahlian dengan tayangan pembelajaran praktik (produktif) yang sebenarnya serta informasi tentang prospek dunia kerja yang bisa diperoleh dari masing-masing kompetensi keahlian; (3) Rekaman film dokumenter sangat mudah untuk digandakan melalui media penyimpanan data, selain itu diunggah melalui website sekolah sehingga bisa ditonton kapan saja dan di mana saja.

\section{TINJAUAN PUSTAKA}

\section{Film Dokumenter}

Konsep film faktual dan film dokumentasi yang berkolaborasi menghasilkan suatu karya film dokumenter atau di program televisi disebut sebagai dokumenter televisi. Film dokumenter marak dibuat dan telah menjadi industri film sendiri yang berkembang pesat di dunia. Film dokumenter berkembang pesat seiring dengan kemajuan teknologi permasalahan yang lebih kompleks dalam kehidupan manusia secara regional maupun internasional.

Menurut Andi Fachruddin dalam bukunya Dasar-Dasar Produksi Televisi (2012), karya dokumenter merupakan film yang menceritakan sebuah kejadian nyata dengan kekuatan ide 
kreatornya dalam merangkai gambar-gambar menarik menjadi istimewa secara keseluruhan. Menurut beberapa tokoh lainnya, istilah dokumenter diartikan sebagai berikut:

a. John Grierson, pertama kali mengkritik film-film karya Robert Flaherty di New York Sun pada 8 Februari 1926. Salah satunya adalah yang berjudul Nanook of the North. Grierson menyampaikan pandangannya bahwa apa yang dilakukan oleh Flaherty tersebut merupakan sebuah perlakuan kreatif terhadap kejadian-kejadian aktual yang ada. A Creatif treatment of actuality (John Grierson) (Fajar Nugroho:2007).

b. Bill Nichols mengatakan film dokumenter adalah upaya menceritakan kembali sebuah kejadian atau realitas menggunakan fakta dan data (Bill Nichols:2001).

c. Paul Wells, film nonfiksi yang menggunakan footage yang aktual, di mana termasuk di dalamnya perekaman langsung dari peristiwa yang akan disajikan dan materi riset yang berhubungan dengan peristiwa itu, misalnya hasil wawancara, statistik dan sebagainya. Film seperti ini biasanya disuguhkan dari sudut pandang tertentu dan memusatkan perhatiannya pada sebuah isu-isu sosial tertentu yang sangat memungkinkan untuk dapat menarik perhatian penontonnya.

d. Frank E. Beaver mengatakan film dokumenter biasanya di-shoot di sebuah lokasi nyata, tidak menggunakan aktor dan temanya terfokus pada subyek-subyek seperti sejarah, ilmu pengetahuan, sosial atau lingkungan. Tujuan dasarnya adalah untuk memberi pencerahan, informasi, pendidikan, melakukan persuasi dan memberikan wawasan tentang dunia yang kita tinggali (Beaver Frank, E.:1994).

e. Timothy Corringan, dokumenter sebuah film nonfiksi tentang masyarakat dan peristiwanya sering kali mengabaikan struktur naratif yang tradisional (Tomothy Corrigan:2007).

f. Ira Konigsberg menjelaskan, dokumenter sebuah film yang berkaitan langsung dengan suatu fakta dan nonfiksi yang berusaha untuk menyampaikan kenyataan dan bukan sebuah kenyataan yang direkayasa. Film-film seperti ini peduli terhadap perilaku masyarakat, suatu tempat atau suatu aktifitas (Ira Konigsberg:1998).

g. Gerald Mastdan Bruce F. Kawn, menekankan dokumenter sebuah film nonfiksi yang menata unsur-unsur faktual dan menyajikannya, dengan tujuan tertentu (Gerald Mast \& Bruce F. Kawn:2005).

h. Misbach Yusa Biran mengatakan bahwa dokumenter adalah suatu dokumentasi yang diolah secara kreatif dan bertujuan untuk mempengaruhi (mempersuasi) penontonnya.

i. Danesi Marcel, film dokumenter adalah "merupakan film nonfiksi yang menggambarkan situasi kehidupan nyata dengan setiap individu menggambarkan perasaannya dan pengalamannya dalam situasi yang apa adanya, tanpa persiapan, langsung ada kamera atau pewawancara. Dokumenter seringkali diambil tanpa skrip dan jarang sekali ditampilkan di gedung bioskop yang menampilkan film-film fitur. Akan tetapi, film jenis ini sering tampil di televisi. Dokumenter dapat diambil pada lokasi pengambilan apa adanya, atau disusun secara sederhana dari bahan-bahan yang sudah diarsipkan" (Danesi Marcel:2010). 
j. Paul Rotha mengatakan film dokumenter adalah mengombinasikan seni pembuatan film, seni produksi, dan penulisan jurnalistik (Paul Rotha, Sinclair Road, and Richard Graffith:1949).

k. Sosuke Yasuma menjelaskan, "Documenter programme to show audience what has never been seen, what has never been told" (mengungkapkan segala sesuatu yang sangat menakjubkan, keanehan, atau keindahan luar biasa, yang kita temukan kepada pemirsa televisi dalam suatu paket/ program televisi) (Sosuke Yasuma:2003).

1. Gerzon R. Ayawaila, dokumenter televisi adalah program dokumenter dengan tema topik tertentu, disajikan dengan gaya bercerita, menggunakan narasi (dengan voice over), menggunakan wawancara, juga ilustrasi musik sebagai penunjang gambar visual (picture story) (Ayawaila Gerzon R.:2009).

Berdasarkan penjelasan beberapa tokoh tersebut, prinsip film dokumenter membiarkan spontanitas objek yang difilmkan bukan rekayasa. Maka objek riset yang menjadi penggerak utama. Ide-ide yang diangkat dari hal-hal yang kecil/sederhana yang mungkin luput dari perhatian yang lain atau kita pada umumnya.

Ide keprihatinan/kejenuhan terhadap fenomena/peristiwa yang terjadi di sekeliling kita. Selanjutnya berangkat dari ide harus dipikirkan tiga hal dasar untuk membuat film dokumenter:

a. Apa yang akan dibuat atau diproduksi?

Produksi film apa yang akan dibuat berdasarkan sesuatu yang nyata, terlewatkan atau enggan dilihat orang umumnya. Lalu membuatnya tidak melibatkan orang banyak, peralatan sederhana, waktu penayangan fleksibel serta mandiri tanpa perlu mengatasnamakan rumah produksi atau stasiun televisi.

Film faktual (news) berarti harus aktual/cepat dan disiarkan pada stasiun televisi, film dokumentasi sifatnya khusus pada kepentingan tertentu atau home use. Adapun perkembangan dari film nonfiksi, yaitu penggabungan film faktual dan film dokumentasi tersebutlah yang menjadi film dokumenter.

b. Bagaimana produk tersebut hendak dikemas: menyangkut pendekatan, gaya, bentuk dan struktur?

1) Pendekatan Film Dokementer

Seorang produser dalam membuat film dokumenter harus menyesuaikan kepentingan dari audience dan pengemasannya sehingga tepat sasaran. Melalui pendekatan esai mengetengahkan secara kronologis atau tematik agar makna yang ingin disampaikan mudah dimengerti dan menarik penyajiannya. Adapun pendekatan naratif menggunakan konstruksi konvensional, yaitu tiga babak penuturan (awal, tengah, dan akhir).

2) Gaya Film Dokumenter

Ada beberapa tipe pemaparan film dokumenter: eksposisi (expository ducumentary), observasi (observational documentary), interaktif (interactive documentary), refleksi (reflexive documentary), performatif (performatife documentary).

Dokumenter eksposisi adalah dokumenter yang paling konvensional atau telah lama digunakan. Merupakan format dokumenter televisi, sebagai ciri khasnya 
menggunakan narator sebagai penutur tunggal, istilahnya Voice of God untuk naratornya.

Dokumenter eksposisi tidak menggunakan narator sebagai pengisi suara, konsentrasi pada dialog antarsubjek. Produser (director) posisinya sebagai observer (pengamat), alur penceritaan cenderung datar.

Dokumenter interaktif, di mana produser berperan aktif (partisipan). Adegan komunikasi antara sutradara dengan subjeknya terlihat jelas. Jika ada wawancara tidak hanya menampilkan adegan wawancara namun juga bagaimana wawancara dilakukan.

Dokumenter refleksi yaitu menggambarkan kamera bagaikan mata film yang merekam berbagai realitas. Fokus utama pengemasannya pada penuturan proses pembuatan shooting film.

Dokumenter performatif fokus utamanya adalah kemasan. Kemasan harus semenarik mungkin, alur penuturan (plot) lebih diperhatikan. Sebagai pengamat memasukkannya sebagai semi dokumenter, bentuk penuturan lebih diperhatikan dibanding film fiksi. Tidak harus berdiri sendiri, secara baku dapat melakukan penggabungan dua penuturan dalam sebuah tema.

3) Struktur Film Dokumenter

Rancangan untuk menyatukan unsur film sesuai dengan ide penulis naskah atau produser. Unsur dasar film: awal cerita (latar belakang/pengenalan), bagian tengah cerita (permasalahan/krisis dan konflik), bagian akhir cerita (kesimpulan/ klimaks/anti klimaks). Ketiga bagian di atas merupakan rangkuman susunan shot gambar yang membentuk suatu adegan (scene). Kumpulan adegan (scene) merupakan bagian dari suatu sequence/induk cerita per bagian. Struktur film dokumenter memiliki makna estetika, psikologis, dan bahasa visual (sinematografi).

c. Untuk apa dan untuk siapa film dokumenter diproduksi? (target pemirsa)

Membuat film dokumenter sejak di awal telah diseting akan disajikan untuk apa dan siapakah audiensinya. Ada film dokumenter yang bertujuan untuk propaganda membangkitkan semangat nasionalisme dan mempengaruhi ideologi politik. Memberikan manfaat ilmu pengetahuan, pengenalan tokoh bersejarah, promosi perusahaan, dan lain sebagainya. Adapun target pemirsanya bervariasi dari masyarakat umum, kelompok tertentu, atau memiliki segmentasi pasar yang spesial.

\section{Masa Orientasi Siswa (MOS)}

Dalam buku "Pedoman Kegiatan Masa Orientasi Siswa (MOS) di SMK" (2001) disebutkan bahwa setiap jenjang pendidikan memiliki ciri khusus yang membedakan dengan jenjang pendidikan lainnya, terutama dalam hal penyampaian materi yang disesuaikan dengan tingkat perkembangan kemampuan mental psikologis anak didik. Ciri kekhususan pada setiap jenjang pendidikan menyebabkan kebiasaan belajar yang dikembangkan sebelumnya ditinggalkan dan diganti dengan cara belajar yang baru sesuai dengan jenjang pendidikan yang didudukinya. Penggantian kebiasaan belajar memerlukan proses tersendiri yang tidak mudah dilakukan oleh setiap anak. Seperti halnya pada minggu pertama 
memasuki jenjang pendidikan yang baru, seringkali diikuti rasa keraguan, kebingungan bahkan menimbulkan ketegangan yang tidak sepenuhnya disadari. Hal ini terjadi karena berada pada lingkungan (fisik maupun sosial) yang baru. Perasaan semacam itu jika dibiarkan secara terus menerus akan membawa dampak terhadap suka tidaknya berada di lingkungan yang baru, bahkan membawa pengaruh terhadap kelancaran dalam belajar.

Upaya mengantisipasi hal-hal tersebut di atas, perlu dilakukan program orientasi yang disebut dengan Masa Orientasi Siswa (MOS). Program ini adalah bagian dari efektif belajar yang merupakan rangkaian kegiatan mengawali pertama masuk sekolah, dilakukan pada setiap tahun ajaran baru. Pemberian MOS kepada peserta didik di SMK mempunyai kekhususan tersendiri, yaitu disamping pengenalan lingkungan sekolah dengan berbagai sarana dan fasilitas, dimaksudkan juga memberikan informasi atau gambaran program studi, dengan cara belajarnya yang lebih menekankan pada peningkatan jam praktik, serta memperkenalkan jaringan relasi dari kalangan usaha atau industri yang berhasil menjalin kerja sama untuk menyalurkan bakat dan prestasi anak didik. Serta permasalahan tuntutan dunia kerja yang bakal dihadapi nanti. Melalui MOS ini diharapkan dapat membangkitkan minat dan semangat belajar untuk mewujudkan cita-citanya.

\section{SMK Negeri 11 Semarang}

SMK Negeri 11 Semarang adalah salah satu Sekolah Menengah Kejuruan Negeri di Jawa Tengah yang mengembangkan Program Studi Keahlian Teknik Grafika dan Teknik Komputer dan Informatika (TKI). Kompetensi Keahlian yang ada meliputi:
a. Persiapan Grafika (Pre Press).
b. Produksi Grafika (Press \& Post Press).
c. Multimedia.
d. Animasi.

Sekolah ini didirikan pada tahun 1990, berdasarkan Keputusan Menteri Pendidikan dan Kebudayaan Republik Indonesia dengan nomor :0389/0/1990 dengan nama SMT Grafika Negeri Semarang dan mendapat NNS : 551036304001. Pada tahun 1997 berdasarkan keputusan Menteri Pendidikan dan Kebudayaan Republik Indonesia nomor: 036/0/1997 tentang perubahan nomor klatur SMKTA menjadi SMK, SMT Negeri Grafika Semarang berubah menjadi SMK Negeri 11 Semarang hingga sekarang.Untuk Kompetensi Keahlian Persiapan Grafika dan Produksi Grafika pada tanggal 13 Oktober 2006 telah terakreditasi dengan nilai A, sedangkan Kompetensi Keahlian Multimedia pada tanggal 12 Desember 2007 juga terakreditasi dengan nilai A.

\section{Kajian Penelitian yang Relevan}

Kajian penelitian yang relevan dengan penelitian yang penulis lakukan antara lain:

a. Fikri Aditya Warma (Jurusan Seni dan Desain - Fakultas Sastra UM, 2007), skripsi berjudul "Perancangan Film Dokumenter Pertunjukan Permainan Tradisional Prisean", menjelaskan bahwa karena adanya keterbatasan media komunikasi dan dokumentasi yang dimiliki, maka diperlukan media baru yang bisa mendokumentasikan tentang pertunjukan permainan tradisioal Prisean secara utuh dan lebih nyata dengan tampilan audio visual dalam bentuk film dokumenter. 
b. Afif Muzayan (Jurusan Sistem Informasi STMIK AMIKOM YOGYAKARTA, 2011), naskah publikasi berjudul "Pembuatan Film Dokumenter Sebagai Media Informasi Pabrik Genteng Massokka". Film dokumenter ini memberikan informasi kepada masyarakat tentang proses produksi genteng Massokka sesuai dengan logline yang telah dibuat. Berdasarkan hasil parameter, film dokumenter ini dinilai baik oleh masyarakat / audiens. Dari parameter tersebut dapat disimpulkan bahwa film dokumenter ini telah sesuai dengan apa yang telah diharapkan.

Berdasarkan dua pustaka di atas, penulis membuat sebuah kajian bahwa informasi tentang segala sesuatu, baik orang, tempat, kejadian, proses kegiatan, ilmu pengetahuan dan lain sebagainya yang sebelumnya belum diketahui oleh masyarakat pada umumnya, melalui film dokumenter informasi tersebut bisa tersampaikan dengan mudah.

\section{METODOLOGI PENELITIAN}

Metodologi penelitian yang digunakan penulis adalah model prosedural yang mengacu pada metode penelitian dan pengembangan (Research and Development/R\&D). R\&D adalah metode penelitian yang digunakan untuk menghasilkan produk tertentu, dan menguji keefektifan produk tersebut. Untuk dapat menghasilkan produk tertentu digunakan penelitian yang bersifat analisis kebutuhan dan untuk menguji keefektifan produk tersebut supaya dapat berfungsi di masyarakat luas, maka diperlukan penelitian. Jadi penelitian dan pengembangan bersifat longitudinal (bertahap bisa multy years). Dalam penelitian ini, penulis menggunakan penelitian dan pengembangan metode Prof. Dr. Sugiyono (2011).

Menurut Sugiyono (2011:409), prosedur penelitian dan pengembangan ditunjukkan pada gambar 1 berikut:

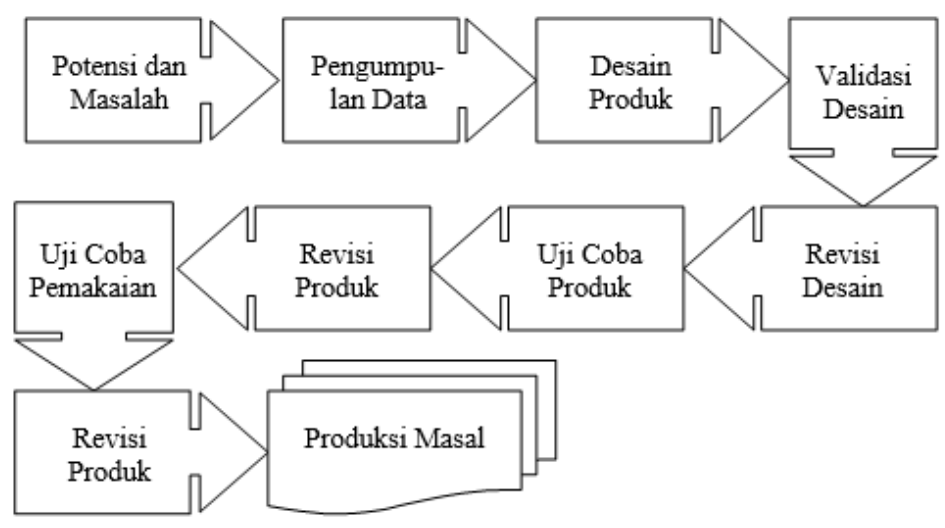

Gambar 1. Prosedur penggunaan Metode R\&D (Sugiyono, 2011)

\section{HASIL DAN PEMBAHASAN}

1. Hasil Penelitian

a. Hasil uji validasi penguji internal (pakar) dan penguji eksternal (pengguna) 
$P=\frac{\text { Skor hasil pengumpulan data }}{\text { Skor ideal }} \times 100 \%$

$P=\frac{150}{4 \times 2 \times 20} \times 100 \%$

$P=93,75 \%$

Jadi, secara keseluruhan uji validator pakar dan pengguna diperoleh angka persentase sebesar 93,75\% dengan kriteria Sangat Baik.

b. Hasil Uji Coba Pemakaian

Berdasarkan data primer (2013) diperoleh hasil bahwa kriteria yang muncul pada setiap responden selanjutnya dihitung jumlah keseluruhan (frekuensi), maka dengan kriteria Sangat Baik sejumlah 90 responden (39\%), kriteria Baik sejumlah 138 responden (61\%), kriteria Kurang Baik sejumlah 0 responden $(0 \%)$, dan kriteria Tidak Baik sejumlah 0 responden $(0 \%)$.

Tabel 1. Persentase hasil analisa perhitungan angket respon siswa

\begin{tabular}{|c|l|r|r|}
\hline \multicolumn{1}{|c|}{ Interval } & \multicolumn{1}{|c|}{ Kriteria } & \multicolumn{1}{c|}{ Frekuensi } & \multicolumn{1}{c|}{ Persentase } \\
\hline $81,26-100$ & Sangat baik & 90 & 39 \\
\hline $62,51-81,25$ & Baik & 138 & 61 \\
\hline $43,76-62,50$ & Kurang baik & 0 & 0,0 \\
\hline $25,00-43,75$ & Tidak baik & 0 & 0,0 \\
\hline Jumlah & & 228 & 100 \\
\hline
\end{tabular}

Dengan demikian, hasil perhitungan uji pemakaian terhadap respon siswa baru peserta MOS SMKN 11 Semarang sebanyak 228 siswa secara keseluruhan diperoleh angka persentase sebesar $\mathbf{6 1 \%}$ dengan kriteria Baik.

\section{Hasil Pengembangan}

Hasil pengembangan pada penelitian ini adalah media informasi film dokumenter dengan spesifikasi sebagai berikut:

1) Judul film : Enjoy with SMKN 11 Semarang

2) Alur/ plot : alur maju.

3) Durasi : 16'51"

4) Format : MP4

5) Software: Sony Vegas Pro 11, Adobe Aftereffect CS5 dan Adobe Photoshop CS3

6) Sinopsis : ada 4 orang sahabat, dari empat kompetensi keahlian di SMKN 11 Semarang, Deni dari Multimedia, Vita dari Persiapan Grafika, Arya dari Produksi Grafika, dan Riska dari Animasi. Ketika mengerjakan tugas produktif (kejuruan), keempat siswa tersebut saling membantu dan berkesinambungan. Tiga tahun kemudian, mereka bertemu kembali dalam keadaan yang berbeda. Menuju masa depannya masing-masing, kuliah dan bekerja.

Langkah-langkah pembuatan film dimulai dari pra produksi (menyusun crew, menentukan pemain, membuat jadwal produksi, skenario, dan storyboard), produksi (take gambar), dan pasca produksi (editing danpembuatan coverDVD). 


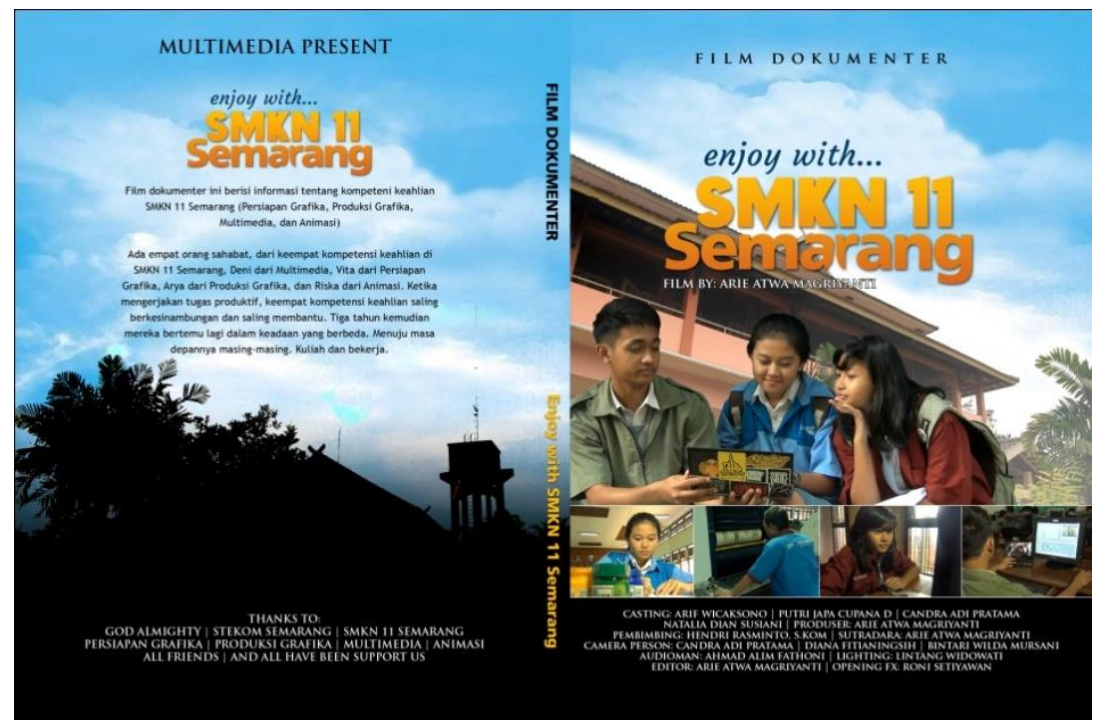

Gambar 2. Cover DVD

\section{KESIMPULAN}

Berdasarkan pembahasan dari penelitian dan pengembangan yang dijabarkan, penulis membuat kesimpulan sebagai berikut:

1. Palaksanaan Masa Orientasi Siswa (MOS) khususnya sosialisasi kompetensi keahlian SMKN 11 Semarang oleh KKK kepada siswa baru dapat berjalan secara efektif dan maksimal dengan didukung media informasi berupa film dokumenter. Hal tersebut dibuktikan dengan respon siswa bahwa sebanyak $78 \%$ siswa menyatakan tampilan visual film bagus, $73 \%$ siswa menyatakan kualitas audio bagus, $80 \%$ siswa menyatakan kontiniti gambar sesuai, dan $73 \%$ siswa menyatakan alur cerita film menarik. Dengan pengemasan audio visual, kontiniti gambar, dan alur cerita yang menarik, film dokumenter mampu menarik perhatian siswa sehingga mereka fokus memperhatikan penjelasan KKK.

2. Siswa memberikan respon positif terhadap implementasi film dokumenter, karena sebanyak 74\% siswa paham tentang pelajaran praktik yang ada pada setiap kompetensi keahlian, sebanyak $76 \%$ siswa mengetahui prospek masa depan/bidang kerja yang bisa diperoleh setelah lulus dari SMKN 11 Semarang, serta $72 \%$ siswa menyatakan jelas dengan informasi yang disampaikan film dokumenter. Dengan dipahaminya informasi dalam film dokumenter tersebut, sebanyak 64\% siswa termotivasi untuk siap mengikuti pembelajaran produktif yang sebenarnya.

3. Berdasarkan penelitian uji validasi pakar dan pengguna, diperoleh persentase sebesar 93,75\% dengan kriteria Sangat Baik. Sedangkan berdasarkan penelitian pada uji coba pemakaian melalui angket respon siswa, diperoleh angka persentase $61 \%$ dengan kriteria Baik. Dengan demikian, hasil penelitian tentang "Film Dokumenter sebagai Media Informasi Kompetensi Keahlian SMKN 11 Semarang" dinilai berhasil.

\section{DAFTAR PUSTAKA}

[1] Al Fajr, Rizky, 2009; "Perancangan Film Dokumenter:Menelusuri Jejak Singhasari", Malang: Universitas Negeri Malang Program Studi Desain Komunikasi Visual, 
[http://library.um.ac.id/freecontents/ index.php/pub/detail/perancangan-film-dokumentermenelusuri-jejak-singhasari-rizky-al-fajr-37212.html].

[2] Corrigan, Timothy, 2007; "A Short Guide to Writing about Film”, New Jersey: Pearson Education.

[3] Direktorat Pendidikan Menengah Kejuruan Departemen Pendidikan Nasional Direktorat Jenderal Dasar dan Menengah, 2001; "Pedoman Kegiatan Masa Orientasi Siswa (MOS) di $S M K$ ”, Jakarta: Bagian Proyek Sistem Pengembangan Kreatifitas dan Karier.

[4] Effendy, Heru, 2009; "Mari Membuat Film", Jakarta: Erlangga.

[5] Fachruddin, Andi, 2012; "Dasar-Dasar Produksi Televisi", Jakarta: Kencana.

[6] Gerzon R, Ayawaila, 2009; "Dari Ide Sampai Produksi”, Jakarta: FFTV IKJ Press.

[7] Hahn, Fred E. dan Kenneth G. Mangun, 1999; "Beriklan dan Berpromosi Sendiri”, Jakarta: Grasindo.

[8] Handry TM, 2006; “Yok Bikin Film Gitu Loh!”, Laba-laba Publisher.

[9] Javandalasta, Panca; "5 Hari Mahir Bikin Film”, Surabaya: Mumtaz Media.

[10] KBBI, 2013; "Kamus Besar Bahasa Indonesia (Kamus versi online/dari dalam jaringan) “, [http://kbbi.web.id].

[11] Konigsberg, Ira, 1998; “The Complete Film Dictionary”, Penguin Papaerbacks.

[12] Kristanto, Andi, 2008; "Perancangan Sistem Informasi dan Aplikasinya", Klaten: Gava Media.

[13] Marcel, Danesi, 2010; "Pengantar Memahami Semiotika Media”, Yogyakarta: Jalasutra.

[14] Mast, Gerald \& Bruce F. Kawn, 2005; “A Short History of The Movies”, Longman.

[15] M. Yusup, Pawit, 2009; “ Ilmu Informasi, Komunikasi, dan Kepustakaan”, Jakarta: Bumi Aksara.

[16] Nichols, Bill, 2001; "Dictionary of Film Terms", New York: An Imprint of Simon \& Schuster Mac-millan.

[17] Nugraha, Yopie, 2011; "Cara Instan Menguasai Program Editing Secara Otodidak", Jakarta:Agogos Publishing.

[18] Nugroho, Fajar, 2007; "Cara Pintar Bikin Film Dokumenter", Yogyakarta: Penerbit Indonesia Cerdas.

[19] Nurdin. S, Usman. Basyiruddin. M, 2002; "Guru Profesional dan Implementasi Kurikulum", Ciputat Pers.

[20] Purnomo, Hermawan Sapto, 2010; "Video Dokumenter Pasar Ngasem Yogyakarta", Yogyakarta: Jurusan Sistem Informasi Sekolah Tinggi Manajemen Informatika Dan Komputer AMIKOM, [journal.amikom.ac.id/index.php/SI/article/.../2643].

[21] Rotha, Paul, Sinclair Road, and Richard Graffith, 1949; "Documentary Film”, New York: Communications Arts Books.

[22] Sugiyono, 2011; “Metode Penelitian Kuantitatif Kualitatif dan R\&D”, Bandung: Alfabeta.

[23] Warma, Fikri Aditya, 2007; "Perancangan Film Dokumenter Pertunjukan Permainan Tradisional Prisean", Jurusan Seni dan Desain - Fakultas Sastra UM, [http://karyailmiah.um.ac.id/index.php/seni-desain/article/view/499].

[24] Yasuma, Sosuke, 2003; "Television Documentray Production”, Tokyo: Text Book. 